九州大学学術情報リポジトリ

Kyushu University Institutional Repository

\title{
The Disintegration of a Traditional System of Exchange Labour and the Mechanization of Paddy Land Preparation in Sri Lanka
}

Ul luw i shewa, Rohana

Seminar of Econometric Analysis in Agriculture, Faculty of Agriculture, Kyushu University

Tsuchiya, Keizo

Seminar of Econometric Analysis in Agriculture, Faculty of Agriculture, Kyushu University

https://doi.org/10.5109/23799

出版情報：九州大学大学院農学研究院紀要. 29 (2/3)，pp.117-138，1984-12. Kyushu University バージョン：

権利関係 : 
J. Fac. Agr., Kyushu Univ., $29(2 \cdot 3), 117 \sim 138$ (1984)

\title{
The Disintegration of a Traditional System of Exchange Labour and the Mechanization of Paddy Land Preparation in Sri Lanka
}

\author{
Rohana Uiluwishewa and Keizo Tsuchiya \\ Seminar of Econometric Analysis in Agriculture, Faculty of agriculture, \\ Kyushu University 46-07, Fukuoka 812 \\ (Received September 28, 1984)
}

\begin{abstract}
The traditional system of reciprocal exchange labour facilitates the continuous existence of labour intensive technology pertaining to paddy farming by providing unpaid labour together with unpaid draught animals and implements in the traditional agrarian society in Sri Lanka. This traditional system is, at present, subject to rapid disintegration due to the various socio-economic changes brought about by the development of the market economy. While the system of exchange labour is disintegrating, hired labour is emerging. Though hired labour provides the necessary man power, it seems to have failed to fill the vacuum because, in contrast to the exchange labour, hired labour involves cash payments. Consequently labour-labour system has become a labour-money system. In addition, hired labour does not provide free of charge draught animals and implements. All these result in incrersed cash cost. Therefore, when the tradition of exchange labour tends to disintegrate, the animal draught power based-labour intensive technology which has been used for paddy land preparation over centuries, has become weak in its ability to compete with its counterpart: mechanical power based-Iabour saving technology. As a result, mechanical power is gaining popularity. Therefore, it seems that the initial transition from exchange labour to hired labour has paved the path for the transition from the animal draught power based-labour intensive technology to the mechanical power based-labour saving technology.
\end{abstract}

\section{INTRODUCTION}

In traditional agrarian societies, paddy is cultivated by peasant farmers whose main production objective is to produce food for family needs at the lowest possible cash cost. Therefore, in contrast to the rationally oriented modern enterprising farmers, these traditionally oriented peasant farmers aim for cost minimization rather than profit maximization. Due to the free or lowered cost of labour, high labour intensive technologies are used. Some farm operations, therefore, need more labour than their unpaid family labour can provide. This is a common phenomenon especially in peak periods. This labour shortage is filled by the reciprocal exchange labour in many traditional agrarian societies. Since this institution provides labour without cash involvements, it facilitates the continuous existence of labour intensive technologies, which enables the labour intensive technology to compete with the more 
efficient and convenient labour saving technology. There is an interdependence between technologies and social institutions. When these institutions tend to disintegrate, the labour intensive technologies too cease to exist.

In the traditional paddy farming society in Sri Lanka reciprocal exchange labour finds articulation in the attama institution. All farmers who cultivate within the same paddy tract, form a group which rotates from one holding to another, performing the given field operation. Therefore, attama mobilizes a sufficient amount of labour into each holding, solving the labour shortage that otherwise would arise. Recently, the attama institution has disappeared in some areas and is being subject to rapid disintegration in other areas. When the attama institution is subject to disintegration, hired labour emerges in it's place. But it seems that the hired labour is not a perfect subsititute for exchange labour. Therefore, the labour intensive technology, having lost its strength to compete with the labour saving technology, is gradually being replaced. Therefore, it seems that the transition from exchange labour to hired labour paves the path for the transition from labour intensive technology to labour saving technology. This paper is intended to highlight this phenomenon in a single field operation of paddy cultivation : land preparation.

\section{DISCUSSION}

\section{Transition from exchange labour to hired labour}

Every dry zonal village ${ }^{1)}$ has been a production unit which was centered around an irrigation tank that provides water for cultivation and human needs. All inhabitants were almost homogeneous in terms of race, caste, and religion. In addition the kinship played an important role in strengthening inter-personal relationship among inhabitants. Every inhabitant had cultivation right on a certain extent of paddy land. Though there were large land holders, in the absence of labour saving technologies and hired labour, the landholders were unable to cultivate the total extent of land by themselves. Thus they had to distribute the cultivation rights of their excess land among small holders and landless people on the basis of share-cropping or rent-inkind. It has never been a custom among villagers to work for wages. Average villager did not choose the occupation of the labourer. His preference was to be either a farmer, artisan or a trader. Only as a last resort would he take up the occupation of a labourer. The low degree of cash involvement has been noticeable in the traditional production system. Paddy has never been a commercial crop. Therefore, there has been no motive to produce a marketable surplus. If there was an excess over family consumption, they used to keep it with them to give in exchange for cloths salt, dry-fish etc.,

1) In the dry zone there are 2 distinct types of settlements such as new settlements and old settlements(villages). While the former type are the settlements which were established under renovated and newly constructed large and medium-sized tanks, the latter type which are based on small tanks, still preserve much of their original traditional characteristics. 
in exchange for the services that they received from carpenters and blacksmiths etc.

Since all farmers in the village cultivated in the same $y a y a^{2)}$ which was irrigated from the village tank, it benefitted everyone to follow a common cultivation calendar. At the beginning of every crop season, all the farmers in the village used to assemble at the village temple to hold a meeting (kanna meeting) which was presided by the village leader ${ }^{3)}$ (Gamarala up to the beginning of the colonial era when he was replaced by VelVidane). At this meeting, decisions on the extent of land to be cultivated (depending on the volume of water available in the tank), kind of paddy to be sown, the dates for the first and last issues of water from the tank, and the time schedule for the whole cultivation operations were made. This tradition has been practiced up till now.

Every farmer used to commence the land preparation after the Liyaddes ${ }^{4}$ were flooded with irrigation water. It has been a long standing tradition among farmers in the dry zone to make soft the paddy soils with water before the land preparation was undertaken. Land preparation has the following component parts.

1. First ploughing

2. Levee repairs. Liyaddes are surrounded by low levees which have to be repaired at the beginning of each season.

3. Second ploughing (approximately 10-15 days after the first ploughing).

4. Harrowing and levelling (approximately 5 days after the second ploughing).

5. Making tiny water channels within the liyaddes.

6. Broadcast sowing of seeds.

The operations such as ploughing and harrowing were performed by buffalo draught power. Each buffalo pair was attached with a country plough if the operation was ploughing, and each pair was driven by one operator. If the operation was trampling, a large buffalo team, approximately 8-10 pairs without attached implements, was driven on the field by one operator. The number of buffalo pairs being employed varied with the size of area to be cultivated and the time available for the operation. These methods of operation remain almost unchanged up to now. This method is quite appreciated by farmers in traditional societies. "A pair of buffaloes weigh about 2,000 pounds. Their feet are just the right shape for pressing down the soil in the paddy field, which results in a gley or crust which holds the water in the soil. The buffaloes also stir up the soils above the gley and loosen it. The buffalo also produces about 1,500 pounds of dung every year and a vast amount of urine, which both contribute significantly to the fertility of the soil"5).

In contrast to the traditional technologies used in other operations, pro-

2) paddy tract fed by the tank.

3) Abysinghe Ariya, 1980.

4) Liyadda, small bunded units within the paddy fields.

5) Gold Smith, E., 1983. 
per application of draught animal power for land preparation requires skilled and well-experienced labour. Experience and knowledge, which should be acquired through working many years with animals, are needed. Anyone would be able to drive a tractor after having a few weeks-training. But, to be able to drive draught animals requires experience over many years. Greater care and experience are needed to handle the plough beam and to keep the depth of ploughing and width between plough-tracks accurate. Also, the proper control of the walking speed and direction of the animals depends on the operator's skill.

Not only the operators, but also the draught animals need a proper training if they are to be used in the field operation. Only the well-experienced operators can train animals. Therefore, the inherited knowledge of operators is very important in keeping the animal draught power in the usage of land preparation. Almost every householder used to keep at least one working animal whereas only a few in a village could possess ploughs, harrowers and levelling boards. Even today, in traditional villages this ownership pattern still remains.

At this point it seems worthwhile to observe how to function the attama institution and the way it facilitated the exisistence of animal draught power based labour intensive technology, and why hired labour is not a perfect substitute for the reciprocal exchange labour.

At the beginning of the land preparation period all farmers who hold cultivation rights on paddy plots in the yaya form a single working group (attama group) which rotates from one holding to another until all the paddy holdings belonging to all participants get ploughed. Therefore, the attama institution functions on a yaya basis. Several groups, however, may be formed in a yaya if the yaya is rather large. In such a case, several attama groups each ranging from 2 to 20 participants, may be formed. Reciprocal exchange is balanced in terms of time, quality of labour, and the type of operation. If one participant received only a half-day service from the attama group to which he belongs he is supposed to work only a half-day in his co-participants' holdings. If he is called for more, he is paid in kind for the extra time. Quality of one's labour is supposed to be dependent on one's age and sex. In the case of an operation for which female labour is needed i. e. weeding or harvesting, a separate female attama group is formed. Attama groups formed for land preparation constitute only adult males. One's failure to work on one of his co-participant's field has to be compensated by sending a substitute who can contribute the same quality of labour. If this is not done, he should pay the cost of the labour time that he was supposed to offer. Also, if the operation for which one received attama labour is ploughing, he should in turn work for all of his other co-participants on the same operation. In this way the balanced-reciprocity in labour supply is maintained in the attama institution. Low cash component involved here makes it more consistent with the peasants' production objective: production for family needs at the lowest possible cash cost. Cash is needed only for provision of Iunch (if the field operation requires full-day work) and other refresments for participants. This 
could also be arranged on credit with a nearby boutique.

The attama institution facilitates the existence of the animal draught power based technology in the following ways.

a. Animal draught power based technology which is inherently labour intensive, requires a relatively greater number of labourers which can hardly be made available during the rather short land preparation period when every farmer is busy. The attama institution enables easy mobilization of labour which is a scarce factor during the land preparation period.

b. As it has been pointed out already, skilled and well-experienced labour is required for the animal draught power based technology. Apart from animal driving; repairing and plastering of levees and making delicate water channels which have to be carefully made within each liyadda, permitting the proper spread of irrigation water throughout each liyadda require great effort and skill. The attama institution assembles all limited experienced labour into each paddy holding, and provides easy access to the available limited skilled labour. At the same time, it provides an opportunity for inexperienced youths to learn from experienced adults.

c. Greater human care and attention is required to maintain the quality of the performance of land preparation. All participants in the attama group may be expected to pay much care and attention to the field operation because A should pay sufficient attention to the performance of tasks relating to B's fields for B to reciprocate in the same manner. Therefore, it seems that reciprocal exchange of labour permits every participant in the group to gain greater care and attention than can be expected from hired labour.

d. Animal draught power based technology requires much water for land preparation. If all farmers in the yaya commenced land preparation on the same day in their individual holdings those who cultivate in the lower end of the yaya would not be able to get sufficient irrigation water since the upper enders impound the liyaddas in their paddy holdings. Attama institution avoids this problem because the attama group starts the rotation from lower end to upper end ${ }^{6)}$.

e. All participants in an attama group are supposed to bring their own draught animals and implements with them. Therefore, under this system all individually owned draught animals and implements are pooled and commonly used. It provides an opportunity for every farmer to get their paddy holdings ploughed in time without facing to any shortage of draught animals and implements. And also, it avoids cash payments which would be involved if hired draught animals are used.

f. When draught animals are used for field operations, the operator's care and kindness to the animal which can only be expected from

6) Karunanayake, M., 1980. 
the owner is considerably important. Also, draught animals are loyal only to their owners who are familiar with them. Since all participants in attama groups attend with their animals, it provides an opportunity for animals to be driven by their owners. This is impractical when hired animals are used.

In this way, it seems that the attama institution makes the animal draught power based-labour intensive technology more consistent with the production system in the traditional agrarian society in two ways. First, the attama institution minimizes the cash involvements and second, it enables the easy mobilization of labour, capital, human skill and experience etc. which are necessary for the existence of animal draught power based technology. Hired labour, which could be used in place of the reciprocal exchange labour, would not be able to play the same role due to its high cash involvements and, as it has been pointed out already, its incapability to mobilize other necessary inputs. Therefore, hired labour, though it merely can provide necessary man power, is not a perfect substitute for the reciprocal exchange labour. It has been evident in Unagaswewa, a dry zonal village where attama institution is non-existent, that scarcity of labour, draught animals, experienced draught animal operators, ploughs and other necessary implements has prevented farmers there from using animal draught power based technology for land preparation". On account of all these evidences it can be concluded that the attama institution makes the animal draught power based technology more consistant with the production objective, resource endowment and the norms of values of the traditional paddy farming agrarian society, enabling that technology to successfully compete with the mechanical power based modern technology. Therefore, when the attama institution is disintegrated the animal draught power based-labour intensive technology gradually begins to lose its strenght which hitherto enabled it to compete with the mechanical power based labour saving technology.

At this point, it seems to be worthwhile to describe briefly the causal fators contributing to the disintegration of the attama institution. An increasing tendancy towards inequal pattern of land ownership in traditional villages makes the balanced reciprocity inherent in the attama institution rather impractical. Being motivated by the increased paddy price and the potential productivity of paddy land which has increased due to biological innovations, rural riches and some urban middle classers become anxious to acquire cultivation rights to paddy lands. One survey has pointed out the increasing intrusion of small-scale businessmen, estate owners, and salaried workers into the village economy in a Kandyan district. For instance, it was found that $2.6 \%$ of the sample controlled $25 \%$ of the paddy land and $17 \%$ of the high land in the villages surveyed". Concerning the Galle district, accumulation of cultivation rights over paddy lands has been pointed out by another sur-

7) Ulluwishewa, R. and K. Tsuchiya, 1984.

8) University of Ceylon, 1957. 
vey". Concerning the dry zone it has been pointed out that it is commercial and credit operation that provide the most effective basis for accumulation by non-cultivator and correspondingly the chief channel for draining the peasant's wealth through marginal profits. These profits are finally invested in land again which results in a transference of land from the actual cultivator to the rentier group. This writer further points out that not only the small businessmen but also small enterprising cultivators too accumulate the cultivation rights on land in traditional villages. For instanse, some of the peasants settled in the older dry zone colonization schemes like Kagama, Minneriya and Polonnaruwa have today ended up as landed proprietors who have bought private land in the nearby traditional villages. Quite usually the road travelled is as follows : 'an enterprising cultivator saves some money from agriculture branches off into shop keeping, money lending, or illicit liquor selling as side activities. As his profits increase, he eschews agriculture, becomes a businessman (Mudalali) and landlord, and finally ends up by buying more land from poverty-stricken villagers"“.. Thus, while the cultivation rights on a certain share of the yaya accumulate into the hands of a few, the remaining paddy lands are continuously fragmentated through inheritance. This process generates a category of very small holders whose family labour exceeds the labour requirement. But they are in short of income. These small holders gradually tend to lose the operational control of their tiny holdings due to any of the following reasons.

a. They may be tempted to sell their small holdings to the rural rich class who offer attractive prices.

b. They may mortgage the holdings and the holdings may be sold at the suit of mortgagee.

c. Their holdings may be sold for debt at the suit of an ordinary creditor.

d. One's tiny paddy holding, in the course of one or two generations may become owned by so many co-owners that its proper cultivation and management becomes difficult and impossible. By successive petitions among co-owners the land may become subdivided into plots of such small sizes as to be of very little use.

In this way, the process of the separation of the farmers from the land comes into the operation. In consequence, a landless class emerges. The inequality emerged in the pattern of land ownership paves the path for the emergence of the following categories.

i . Non-resident land holders

ii. Part time farmers

iii. Large farmers

iv. Small farmers

v. Landless labourers

The emergence of these categories exerts negative impact on the very

9) Das Gupta, 1939.

10) Tambiah, S. J., 1963. 
existence of the attama institution. Attama institution is practical only if all cultivators in the yaya contribute their labour to the farm operation. But the category (i), most probably comprises white-collar occupants in towns, do not present themselves in any kind of activity relating to the cultivation of their paddy lands. A resident farmer, a respectable figure in the village community, who acts as a care taker (Gambaraya) cultivates the non-resident land holder's paddy lands by employing hired labourers. Part-time farmers ,mostly are traders, rice-millers, teachers and white-caller occupants etc., whose non-farm income and the social status are high, find the opportunity cost of their own labour is higher than the hired labour wage rates. Therefore they withdraw themeselves from attama group and tend to employ hired labourers. They themselves play only the role of supervisors.

On the other hand, the small farmers who are not in need of the help of outside labour to supplement the family labour understandably tend to withdraw themselves from attama groups. Since they are in short of the cash income to support their family needs, they may find advantages of being part. time hired labourers. There may be a certain number of marginal small farmers who need a little help of outside labour. They may also find the relative disadvantage of taking part in attama groups. Since the attama group which is functioned on yaya basis is opened to all cultivators in the yaya, the small farmers cannot limit the number of participants to the number of labour units that are needed because it is normally against the tradition to refuse anyone who wishes to participate in an attama group. Therefore, the small farmers may receive excess labour. Since the host farmer is obliged to provide lunch and other refreshments to all participants, in view of the expenditure on food and other items, receipt of attama labour may be not so advantageous to all farmers. Besides, he becomes under the obligation of working for all participants including those whose labour was really unnecessary. Therefore, in view of the increased food prices and the cash income that the small farmer could earn by working for wages instead of working in exchange for the unnecessary labour that he received, he may find the advantages of the application of hired labour. Therefore, the small farmers too tend to withdraw themselves from the attama group.

Only the category of large farmers, in this case defined as the farmers whose family labour is insufficient to meet the labour requirement, find the advantage of attama labour. But when the majority of cultivators in the yaya tend to leave the attama group, they too find it difficult to rely on exchange labour. This is specifically true when the time period available for the particular operation is strictly limited. In such a situation it may be risky for large farmers to wait for exchange labour. And also when many cultivators leave the attama group, labour of the remaining few participants may not be sufficient to meet the large farmers' labour requirement. In such a situation he has to take part in several attama groups in order to collect sufficient labour on exchange basis. This is also rather impractical due to the pressure of time. Therefore, the large farmers too may find the relative advantage of using hired labour. In consequence they too tend to withdraw themselves 
from the attama groups.

In this way, the growing inequality of the land ownership pattern appears to attack at the very roots of the attama institution. Apart from that inequality in the ownership pattern of draught animals and agricultural implements also makes the attama institution less practical, because a perfect at . tama partner should possess at least one draught animal and a few items of simple hand tools. When the number of perfect attama partners declines the benefits that one can gain by participating in a attama group also decline. In the meantime, the attractive wages offered by cash crop cultivators (most of them are non-resident land holders motivated by the increased prices of some cash crops i. e. chillies, tobacco and onions), successfully attract farmers' spare time $^{11)}$. Especially small farmers who are not much benefitted by attama institution may find that buying the small number of labour units that they need and selling their own labour is more advantageous than receiving and offering labour on an exchange basis. In this way while the attama institution tends to disintegrate in the traditional villages, in the new settlements there is no scope to emerge such a co-operation due to the social heterogenity. For the new settleements, settlers are selected from various areas regardless of the cultural differences. Therefore, there is a lack of scope to develop inter-personal trust, mutual understanding and leadership which are the inevitable pre-requisites for the emergence and existance of the attama institution.Also, strictly time-scheduled cultivation operation and rather large sized paddy holdings in the new settlement schemes make it difficult to rely on exchange labour.

When an attama institution begins to disintegrate the alternative which emerges in its place is hired labour. As pointed out already, it is not a perfect substitute for attama labour due to two main reasons.

i . In contrast to the attama labour, hired labour itself involves cash payments. Also, since it does not provide free of charge draught animals and implements, the added expenditure on hired draught animals and implements further raises the cost incurred in draught animal power based-labour intensive technology.

ii. In contrast to the attama labour, hired labour does not facilitate the easy mobilization of labour, capital, human experience, skill, and inherited knowledge which are inevitable in the application of draught animal power based labour intensive technology.

Therefore hired labour apparently fails to fill the vacuum created by the disappearance of attama institution. However, at the early stage of the disappearance of attama institution, non-resident land holders and part time farmers who already left attama groups find difficulties in mobilizing labour on wage basis because those who used to offer their labour on exchange basis, under the new situation, are reluctant to work for wages. In the meantime, the landless people who already lost their cultivation rights on the land they previously had, begin to see work for wages. But at the early stage when

11) Gunasinghe, N., 1976, Karunanayake, M., 1980. 
they are little in number, they can hardly provide the larger labour teams required for traditional technology. At this stage, those who required labour have an alternative method: labour saving technologies. But the landless people have no alternatives but to sell their labour. Therefore, the landless class initiates a certain strategy to cope with the situation. It is the socalled attama contracts ${ }^{12)}$ which have emerged in some areas where the rising inequality in land ownership begins to exert a negative impact on the attama institution.

Under this system a landless villager acts as a middleman between the two parties. One party consists of part time farmers (or large farmers who are not willing to take part in attama group) and non-resident land holders; and the other party consists of farmers who still take part in the attama group. The landless villager enters into a contract or agreement with the first party to uhdertake the responsibility of performing of a given farm operation. It is a pure monetary agreement. The monetary value of the agreement is roughly equivalent to the wages of men who are employed for a particular operation. Then the contractor, a landless villager, will join a attama group; and in exchange for his own labour that he will provide to all other co-participants, he will bring the whole group to his contractee's farm. This method, from the contractee's part, solves his problem, facilitating easy mobilization of labour, capital, skill etc. and from the contractor's part solves his problems, providing a way of cash income.

The continuous concentration of land ownership, on the one hand, sepates the farmer from the land, expands the landless class which provides fulltime hired labourers; and on the other hand, destoroys the attama instutution, and raises the demand for hired labour. In this way, though it is not a perfect substitute for attama labour, hired labour begins to emerge in its full scale in place of the attama labour. zation

Impact of the transition from exchange labour to hired labour on mechani-

In this section, attemps will be made to ascertain the impact of the above discussed labour transition on the transition from the animal draught power based-labour intensive technology to the mechanical power based-labour saving technology. Method adopted to ascertain it, entails testing of the following hypotheses :

(a) When the attama institution disintegrates, application of hired labour increases.

(b) When the hired labour application increases the cash expenditure on labour, draught animals and implements, troubles and inconveniences in mobilization and supervision of labour also increase.

(c) As a result, farmers shift from the animal draught power based-labour intensive technology to the mechanical power based-labour saving technology.

Attempt taken to test these hypotheses is encountered by the following

12) Gunasingha, N., 1976. 
two methodological problems :

1. In fact, any attempt to test a hypothesis dealing with a transitional process requires time-series data. Unfortunately, reliable time-series data pertaining to transition from exchange labour to hired labour, and to farmers' tendency to mechanization can hardly be made available.

2. Troubles and inconvenience involved in hired labour application are less amenable to quantitative analysis. Therefore it is extremely difficult to ascertain the impact of this fact in quantitative terms. For this reason, attempts have been made to evaluate only the measurable factors. But it does not imply any underestimation of the non-measurable factors.

In an attempt to solve the first problem, strategy based on the following logical basis has been adopted.

The working capacity of the family labour available per farm household does not normally increase in proportion to the working load which rises as the operated area increases in extent. Therefore, since the total labour requirement for land preparation per farm is determined by the size of operated area, the number of outside labourers required per farm rises as the size of operated area rises. On this principle, it has been felt that perhaps the best way to solve this methodological problem is to make available cross-sectional farm-level data on farm size and the number of family labour days, exchange labour days, and hired labour days used for land preparation in a village where the transition from exchange labour to hired labour is still in progress.

Therefore, a socio-economic survey has been executed in Nallamudewa, a dry zonal traditional village where the paddy land preparation is totally performed by buffalo power in combination with family, exchange, and hired labour in 1983 May referring to 1982/83 Maha season (Maha is the major crop season extending from Octorber to March). In this survey, a questionnaire was administered to randomly selected 33 households. In addition, necessary information and socio-economic data concering the area, have been collected from official records maintained by the village extension officer (Grama Sevaka) and the cultivation officer. In order to make available the necessary time-series data on labour wage rates and tractor hire rates, and also to gather information concerning the changing situation in the farm power hire market, a brief survey has been conducted in Ambalanthota area, a well advanced paddy cultivating region, where farmers heavily depend on tractors and power tillers for farm power. In this survey, data and information have been collected from informal discussions with a number of randomly selected tractor owners and old aged farmers. The required national level data have been collected from various published reports.

Nallamudewa is located in the Anuradhapura district of the dry zone of Sri Lanka. It is 120 miles away from Colombo, the capital of the country. The five mile long cart track links Nallamudewa to the bus road at Eppawela, a small local town which is located 16 miles away from Anuradhapura. The accessibility of the village is hindered by the absence of a motorable road to this village. Therefore, it is evident that $\mathbf{N a l l a m u d e w a}$ as well as its neigh- 
Table 1. Labour Application for Paddy Land Preparation per Farm by Labour Types in Nallamudewa

\begin{tabular}{lcc}
\hline $\begin{array}{c}\text { Family Labour } \\
(1)\end{array}$ & $\begin{array}{c}\text { Exchange Labour } \\
(2)\end{array}$ & Hired Labour \\
\cline { 2 - 3 }$(6.99$ & a. 33 & 14.68 \\
\hline \\
Unit: percentage \\
Source: Field survey, 1983.
\end{tabular}

Table 2. Size of Operated Area per Head among Part-time Hired Labourers and Non-hired Labourers in Nallamudewa

\begin{tabular}{|c|c|c|c|}
\hline $\begin{array}{c}\text { Part-time Hired } \\
\text { No. of Samples } \\
\text { (1) }\end{array}$ & $\begin{array}{l}\text { Labourers } \\
\text { Average size } \\
\text { of Operated Area } \\
\text { (2) }\end{array}$ & $\begin{array}{l}\text { Non-hired L } \\
\text { No. of Sample } \\
\text { (3) }\end{array}$ & $\begin{array}{l}\text { Average size } \\
\text { of Operated Area } \\
\text { (4) }\end{array}$ \\
\hline 13 & 0.85 & 20 & 1.27 \\
\hline
\end{tabular}

bouring villages is rather isolated. This village has a total of 120 households whose main source of income is paddy cultivation which is based on irrigation water provided by the small village tank. While paddy is cultivated below the tank, chena cultivation is pratised on the unirrigable land.

It seems that the attama institution in Nallamudewa is in the process of disintegration and hired labour is emerging in that place. The composition of labour applied for paddy land preparation (Table 1) shows that the hired labour component plays a significant role in labour supply next to the family labour, and the role of exchange labour is negligible. The disintegration of attama institution appears to have stemmed from the unequal pattern of the distribution of land ownership (Figure 1). However hired labour supply has not yet been fully developed. Only some small farmers whose family income is hardly sufficient to meet the family needs work as part-time hired labourers. It has been found that the extent of paddy land per head among part-time hired labourers is significantly lower than that among others (Table 2). It shows the fact that their economic hardship has generated compelling grounds for them to sell their labour to supplement the insuffi cient farm income. In the future, with the countinuing land fragmentation, this category may fall down to the landless status and will join the full-time hired labour force.

However at present, the rapid disintegration of the attama institution appears to generate labour shortage in peak periods. Especially, the paddy land preparation has to be completed within the possible shortest period regardless of the extent of area to be cultivated and the method of land preparation. Since the animal draught power based-labour intensive technology is inherently labour intensive, large number of labour units and buffaloes have 
$\%$ OF

PADDY EXTENT

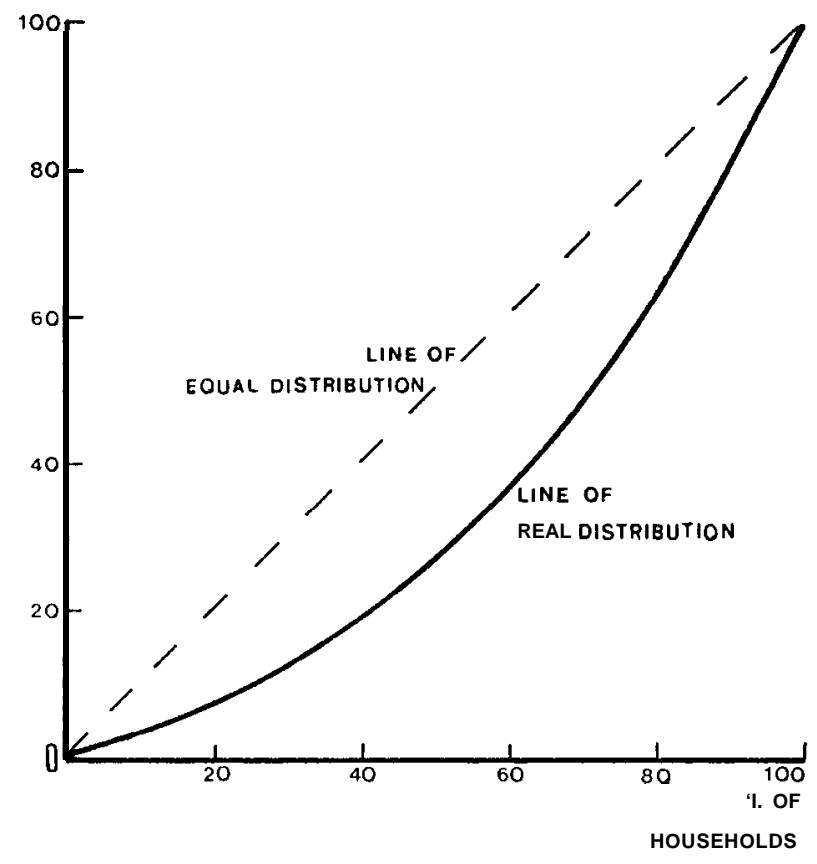

Fig. 1. Distribution of Paddy Land Ownership in Nallamudewa Source: Field survey, 1983.

to be mobilized under the pressure of time. Under the former situation, the attama institution facilitated the easy mobilization of labour and buffaloes. When attama begins to disintegrate the farmers have the two following alternatives :

1. To proceed with buffalo power with the help of hired labour.

2. To shift from the buffalo power based technology to the mechanical power based technology.

Table 3. Average Annual Household Income, Price of Tractors and Average Tractor Hire Charges in Nallamudewa

Average Annual Income Price of Tractor Price of Power-Tiller Average Tractor

$\begin{array}{ccc}(1) & -\frac{(2)}{172,500.00}-\frac{(3)}{3,089.37} & 31,000.00\end{array} \frac{\begin{array}{c}\text { Hire Rate } \\ (4)\end{array}}{500.00}$

Unit: Rupees, 1 Rupee $=¥ 11$ in 1984

Note: (2)Massy Furguson 240 Tractor, 1981

(3) Kubota 2-wheel Tractor, 1981

Source: (1)and(4), Field survey, 1983

(2)and(3), Price list, State Trading (Tractor) Corporation, Colombo. 
Table 4. Resons given by Farmers for their Preference to Animal Draught Power for Paddy Land Preparation in Nallamudewa

\begin{tabular}{|c|c|c|c|c|}
\hline & $\begin{array}{l}\text { Resons } \\
\text { (1) }\end{array}$ & $\begin{array}{c}\text { First } \\
(2)\end{array}$ & $\begin{array}{l}\text { Second } \\
\text { (2) }\end{array}$ & $\begin{array}{c}\text { Third } \\
\text { (3) }\end{array}$ \\
\hline (A) & Owned buffaloes are sufficiently Available & 10 & 1 & 0 \\
\hline (B) & Buffaloes are easily obtainable from neighbours & & & \\
\hline & on late payments in kind or cash & 8 & 2 & 3 \\
\hline (C) & Buffalo ploughing is less expensive & 0 & 12 & 5 \\
\hline (D) & $\begin{array}{l}\text { Quality of performance is better if buffalo } \\
\text { power is used }\end{array}$ & 1 & 4 & 13 \\
\hline$(\mathrm{E})$ & Difficulties in obtaining tractors & 2 & 2 & 3 \\
\hline (F) & Tractor hire rates are too high & 12 & 8 & 2 \\
\hline
\end{tabular}

Source: Field survey, 1983.

The second alternative, tractor based strategy is, in view of the higher market prices of tractors and greater hire rates, positively non-acceptable to farmers (Table 3). When they were asked to rank a given list of reason for their preference to buffalo power for land preparation, a greater majority of farmers emphasized the high cost of tractor hire rates (Table 4). This is not suprising when the tractor hire rates prevailing in this area is compared to the average cost incurred in the buffalo power based method (Table 5). Also, it is strongly contradictory to the farmers' production objective: to produce food for family at the possible lowest cost. Furthermore, due to the prevailing uncertain production conditions and low labour productivity, farmers highly negatively react to any increase in cash investment.

The next alternative is to continue with the buffalo power based-labour intensive technology with the help of hired labour. Although hired labour too involves cash payments, considering its cost advantage relative to the tractor hire charges, farmers decide to continue with it. In this way, the far-

Table 5. Average Cost of Paddy Land Preparation by Farm Power Types in Nallamudewa

\begin{tabular}{ccc}
$\begin{array}{c}\text { Tractors } \\
\text { (Hire Rate) }\end{array}$ & \multicolumn{4}{c}{$\begin{array}{c}\text { Animal } \\
\text { (Including the imputed cost of } \\
\text { family and exchange labour) } \\
\text { (1) }\end{array}$} & $\begin{array}{c}\text { (Excluding the imputed cost of } \\
\text { family and exchange labour) }\end{array}$ \\
\hline 500.00 & 309.25 & 173.50 \\
\hline
\end{tabular}

Unit: Rupees

Note: (2), A Average number of man days required per acre (6.37)

B Labour wage rate (Rs. 25.00 per day)

C Cost of buffalo/Acre (hire charge) (Rs. 150.00)

Total average cost A x B $+\mathrm{C}=$ Rs. 309.25

(3), A Average number of family and exchange labour per acre (5.43)

B Labour wage rate (Rs. 25.00)

C Total cost per acre (Rs. 309.25) Total average cost excluding the cost of family and exchange labour $C-(A \times B)=$ Rs. 173.50

Source: Field survey, 1983. 
mers'shift from exchange labour to hired labour paves the path towards mechanization. In other words, the transition from exchange labour to hired labour initiates circumstances which raise the cash cost incurred in traditional labour intenisive technologies used in various farm operations including land preparation. This transition will later, induce farmers to shift from traditional labour intensive technologies to modern labour saving technologies.

However, as mentioned already since hired labour is not a perfect substitute for exchange labour, as the percentage of hired labour to total labour per farm rises either temporally or spacially, the likelihood of the occurance of the shift from labour intensive technologies to labour saving technologies rises. It is logically true that the total labour requirement per farm is determined by the farm size provided that the technology remains unchanged. Therefore, since the family labour available per farm, in general, does not rise in proportion to the increasing farm size, the percentage of hired labour required per farm rises as the farm size increases. In order to find factual evidence for this argument, attempts have been made to identify farmers' changing behaviour in decision making on alternative labour types as the size of operated area increases in extent. In order to observe the relationship between the size of operated area (paddy extent cultivated by individual householders during the $82 / 83 \mathrm{Maha}$ ) and the types of labour applied for land preparation, the surveyed farm households were categorized into sized-classes (Table 6). Findings are as follows.

a. Farmers who cultivate on tiny farms can manage with their family labour. As the size of operated area increases they seek the help of outside labour: either exchange labour or hired labour.

b. The percentage of exchange labour to total labour, at first, increases with the increasing size of operated area up to a certain level and then it begins to decline, whereas the percentage of hired labour to total labour continuousely increases with the increasing size of operated area.

These findings suggest that as the operated area rises, at first, farmers make effort to manage with their own family labour which is perceived to be an unpaid item and then to find the help of exchange labour which is also an

Table 6. Labour Composition in Relation to the Sized-Class of Operated Area* of Paddy in Nallamudewa

\begin{tabular}{|c|c|c|c|c|}
\hline $\begin{array}{l}\text { Number of Samples } \\
\text { (1) }\end{array}$ & $\begin{array}{c}\text { Sized class } \\
\text { (2) }\end{array}$ & $\begin{array}{c}\text { Family Labour } \\
\text { (3) }\end{array}$ & Exchange Labour & Hired Labour \\
\hline $\begin{array}{r}13 \\
8 \\
12\end{array}$ & $\begin{array}{r}0-\overline{1} .0 \\
1.0-2.0 \\
2.0-4.0\end{array}$ & $\begin{array}{r}100.00 \\
82.41 \\
70.36\end{array}$ & $\begin{array}{l}0.00 \\
7.24 \\
6.67\end{array}$ & $\begin{array}{r}0.00 \\
10.34 \\
22.92\end{array}$ \\
\hline
\end{tabular}

Unit: (2) Acre

(3), (4) and (5) percentage

Note: *Operated area is defined as the extent of area cultivated by individual householders during the 1982/1983 Maha season.

Source: Field survey, 1983. 
unpaid item. Those who failed to manage with both due to the larger operated area or else, as the last resort, tend to employ hired labour. It seems that up to the level of two acres of operated area, farmers are able to find labour on an exchange basis. Beyond that level the likelihood of finding exchange labour begins to decline. At last, at the size of 3-4 acres this reaches the zero level. As it has been mentioned already, it is quite difficult for large farmers to offer their own labour for others on an exchange basis and also to wait for others until they release themselves from their own farm work during busy periods. In consequence, if they want to continue with the buffalo power based-labour intensive technology they have to employ hired labourers. Therefore the percentage of hired labour to total labour per farm continuously rises as the size of operated area rises. Therefore it can be concluded that if the buffalo power based-labour intensive technology is used in the absence of attama institution, the share of hired labour rises as the operated area rises in extent.

Then, in order to ascertain the cost disadvantage involved in the application of hired labour, the cash expenditure on labour for each size category has been estimated (Table 7 , for the method of estimation, refer to the foot

Table 7. Estimated Cash Expenditure on Labour by Sized Classes of Operated Area in Nallamudewa

\begin{tabular}{cccccr}
\hline Sized Class & $\begin{array}{c}\text { Family Labour } \\
\text { available per } \\
\text { Farm }\end{array}$ & $\begin{array}{c}\text { Total Labour } \\
\text { Required }\end{array}$ & $\begin{array}{c}\text { Out-side Labour } \\
\text { Required }\end{array}$ & \multicolumn{2}{c}{$\begin{array}{c}\text { Cash } \\
\text { Labour }\end{array}$} \\
$(1)$ & $(2)$ & $(3)$ & (4) & per Farm & $\begin{array}{c}\text { perAcre } \\
(5)\end{array}$ \\
\hline 0.5 & 4.5 & 3.1 & 0.0 & 0.0 & 0.0 \\
1.0 & 6.2 & 6.3 & 0.1 & 3.7 & 3.7 \\
1.5 & 7.8 & 9.5 & 1.7 & 42.6 & 28.4 \\
2.0 & 9.4 & 12.7 & 3.2 & 81.7 & 40.8 \\
$3: 0$ & 12.7 & 19.1 & 6.3 & 159.8 & 53.2 \\
4.0 & 15.9 & 25.4 & 9.5 & 237.9 & 59.4 \\
\hline
\end{tabular}

Units: (1)Acres, (2), (3), and (4) Man days; (5)and (6) Rupees

Note : Method of estimation

Column (2), $\mathrm{X}=$ Size of operated area

Y-Family labour days applied per operated area

$\mathrm{Y}$ was regressed on $\mathrm{X}$, and parameters of the regression line are as follows

$\mathrm{Y}=2.975+3.247 \mathrm{x}$

(2.465) (5.692) $\mathrm{r}^{2}=0.715$

Then, figures under column (2) have been estimated according to the above equation

Column (3), According to the survey data, average labour requirement for land preparation was 6.37 man days per acre. Therefore $(3)=6.37 \times(1)$

Column $(4),(4)=(3)-(2)$

Column (5), Prevailing labour wage rate of buffalo operetors, according to the survey, is Rs. 25.00 per day. Therefore $(5)=(4) \times$ Rs. 25.00

Column $(6),(6)=(5) /(1)$

Source: Estimation is based on field data, field survey, 1983. 


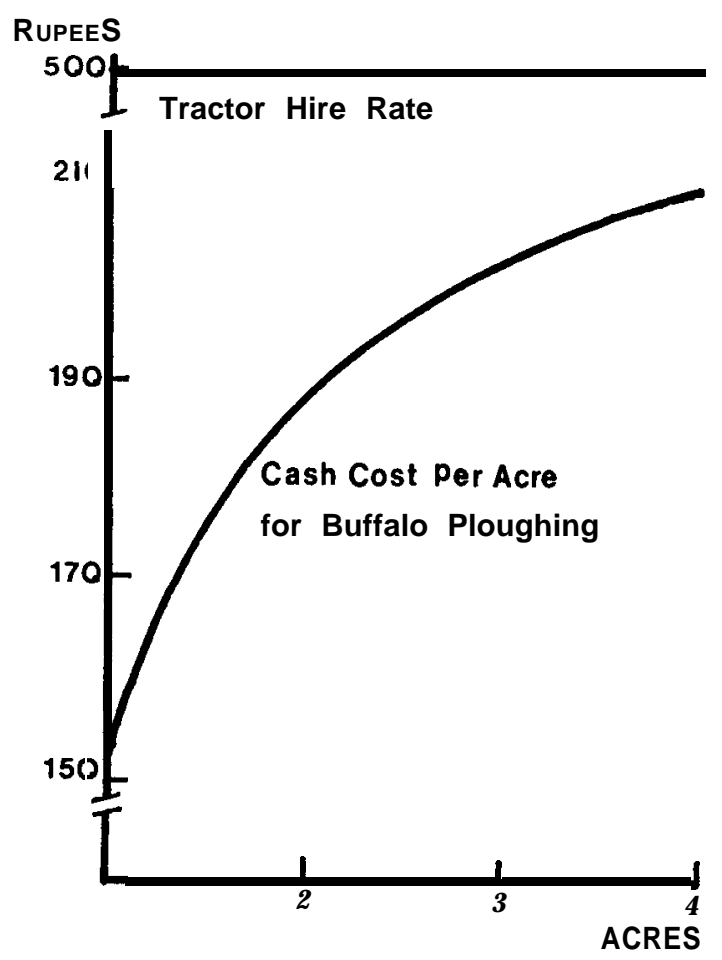

Fig. 2. Cash Cost of Land Preparation by Power Types and Size of Operated Area in Nallamudewa.

Note: Average cost of land preparation has been estimated as follows.

A =Labour cost per acre: As in Table 7 Column 6

$\mathrm{B}=$ Buffalo hire rate: Rs. 25.00 per day (Source: Field survey, 1983)

$\mathrm{C}=$ Number of buffalo-pair days required per acre is 6 (Source: Field survey, 1983)

Therefore, average cost of land preparation $=\mathrm{A}+(\mathrm{B} \times \mathrm{C})$

Tractor hire rate prevailing in this area is Rs. 500.00 per acre (Source:

Field Survey, 1983)

note under the table). According to the estimation, not only the number of hired labor units per farm, but also the number of hired labour units per unit area increases as the size of operated area increases. Therefore the cash expenditure on labour per unit area rises with the increasing size of operated area (Figure 2). This fact raises an important point: if the traditional labour intensive technologies are practised in the total absence of traditional attama labor, the cash costs per unit area also moves upward as the size of operated area increases. But if the modern labour saving technologies are used on contract basis as is normally done in Sri Lanka, the cash expenditure on farm operations (in this case the tractor hire rates) remains unchanged regardless of the size of operated area.

On account of these findings, the following conclusions can be made. 
a. When the attama institution disintegrates hired labour emerges in it's place. In consequence, the percentage of hired labour to total labour per farm rises.

b. As the perpentage of hired labour to total labour rises, cash cost per unit area rises. This cost disadvantage coupled with the troubles and inconveniences involved in hired labour application generates disincentives for the animal draught power based-labour intensive technology. It indirectly favours mechanization due to the following reasons :

i . Tractor hire rates remain unchanged regardless of the changing size of operated area.

ii. Tractor usage for land preparation does not create troubles and inconveniences as the application of hired labour with buffalo power.

c. Therefore, when the attama institution disintegrates, the resulting transition from exchange labour to hired labour paves the path for mechanization.

It seems worthwhile to proceed the analysis in this line to predict the future situation. Under the traditional system, as long as the unpaid labour (family and exchange) is sufficiently available for land preparation, labour wage rates and tractor hire rates do not exert any influence upon the farmers' decision making on farm power selection. Disintegration of attama institution

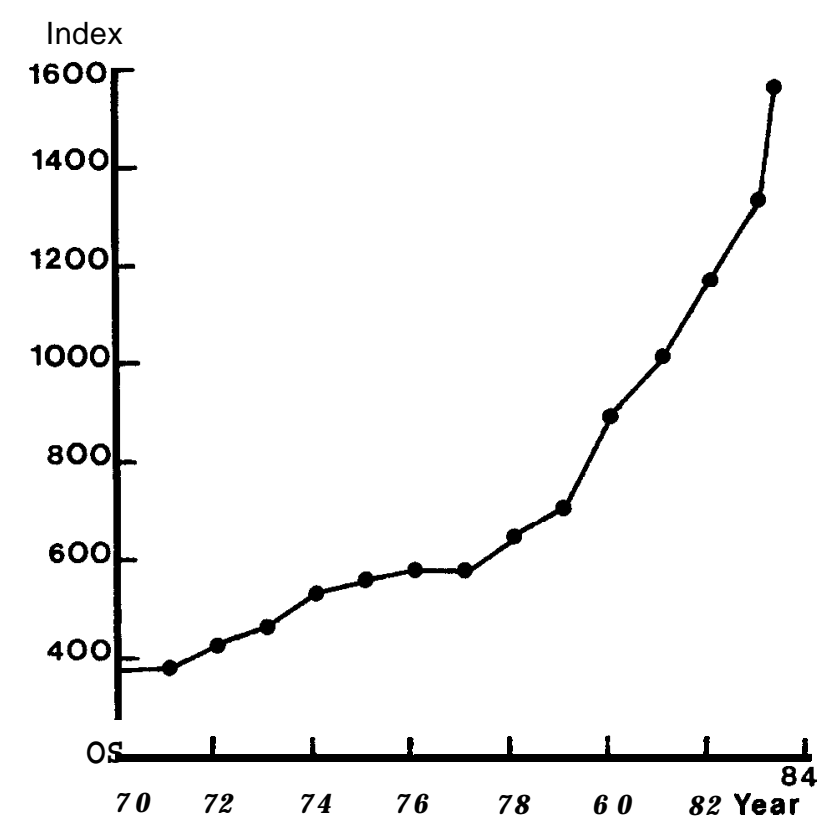

Fig. 3. Cost of Living Index-Colombo (1970-84)

Source: Central Bank of Ceylon, Bulletin, May 1984. 
exposed the rural paddy farming community to the external forces such as labour wage rates and tractor hire rates. In this way, the traditional economy has come under the influence of external market economy. Therefore, under the present situation, tractor hire rates and wage rates of hired labour required for draught animal power are emerging as crucial factors.

Recently, due to the escalating cost of living, as it is shown in Figure 3, the hired labour wage rate is tending to rise at a remarkable rate. The fulltime hired labourers, and the landless people who almost completely depend on the open market for their basic needs, are directly affected by the rising cost of living. In consequence, though they are not in a strong bargaining position, all of them have to claim higher wages for their very survival. Though tractor owners are also affected by the rising cost of living, they are able to cope with it without raising their hire rates in equal proportion, by virtue of the greater operational scale of their farm and non-farm businesses. In the mean time, after the import liberalization in 1977, tractor importation has began to rise at a remarkable rate (Figure 4). Since then, the rising competition among tractor owners to secure the minium number of customers that they need to keep their business profitably, appears to supress the monopolistic power that they maintained hitherto on the farm power hire

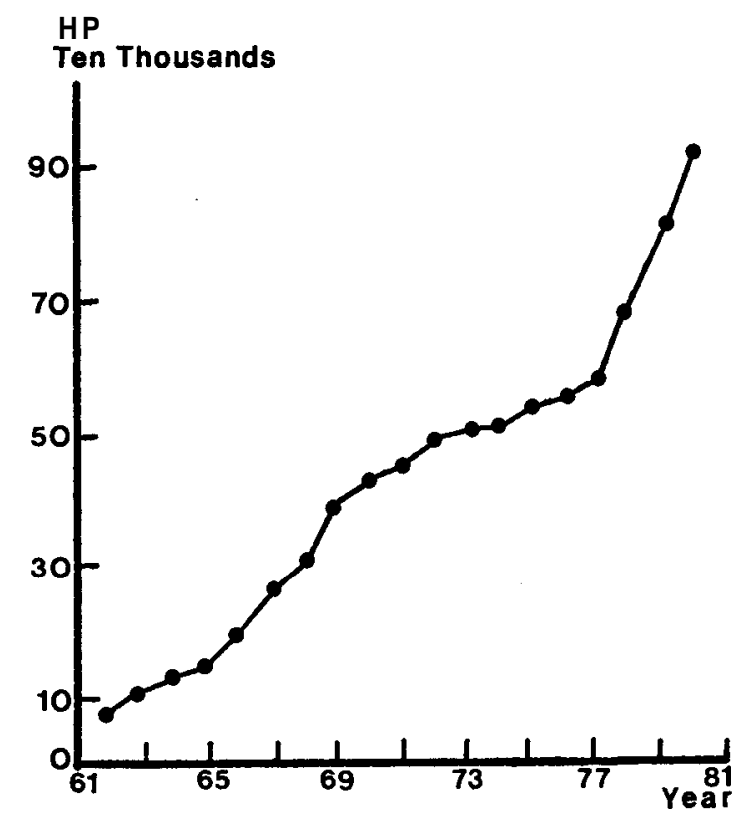

Fig. 4. Growth of Tractor Fleet in Sri Lanka

Note : Tractor $=45 \mathrm{HP}$

Power Tiller=7 HP

Source : New Registration Records, Statistics Division, Commissioner of Motor Traffic, Colombo. 
market. As it is shown in figure 5, up to the $1977 / 78$ period, the tractor owners have managed to increase their hire charges at a rate higher than of the fuel prices. After that period, the increasing rate of tractor hire charges has become lower than that of fuel prices. It was been learned from informal discussions with some tractor owners in the Ambalanthota area that they were dissatisfied with the prevailing demand for custom works and the current hire rates. Until recently, they have successfllly managed to pass over the increased cost of fuel to hirers, keepings their own profit margin unchanged. Under the present situation, they have to forgo a certain share of their profits in order to keep their regular customers. Whatever the reason may be, under the present situation the increasing rate of tractor hire charges appers to be lower than that of labour wages. (Figure 6). This tendency

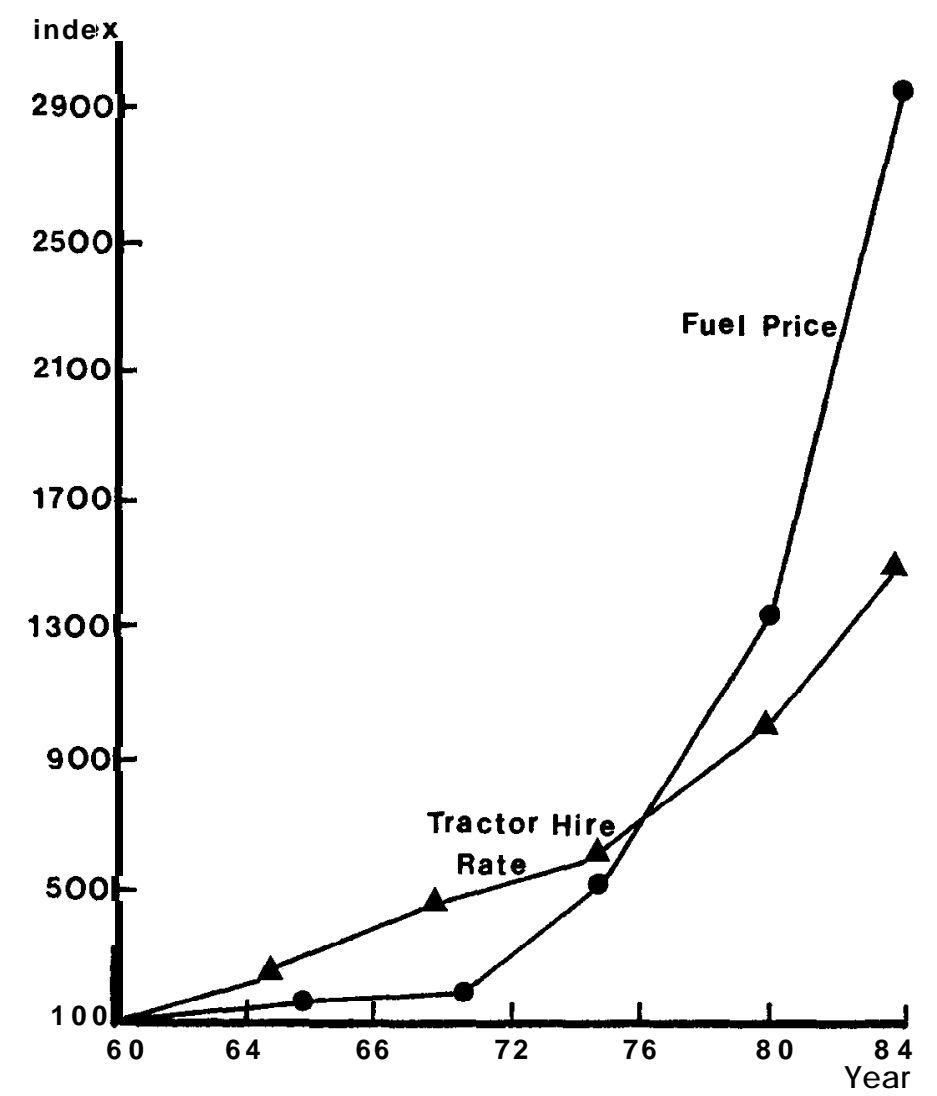

Fig. 5. Index of Tractor Hire Rates and Fuel Prices (1960-1984) in Sri Lanka.

Note: $1960=100$

Source: Fuel prices, Budget Section, Ceylon Petroleum Corperation, Colombo. Data on tractor hire rates were collected from personal communication with a number of randomly selected farmers in Ambalantota area. 


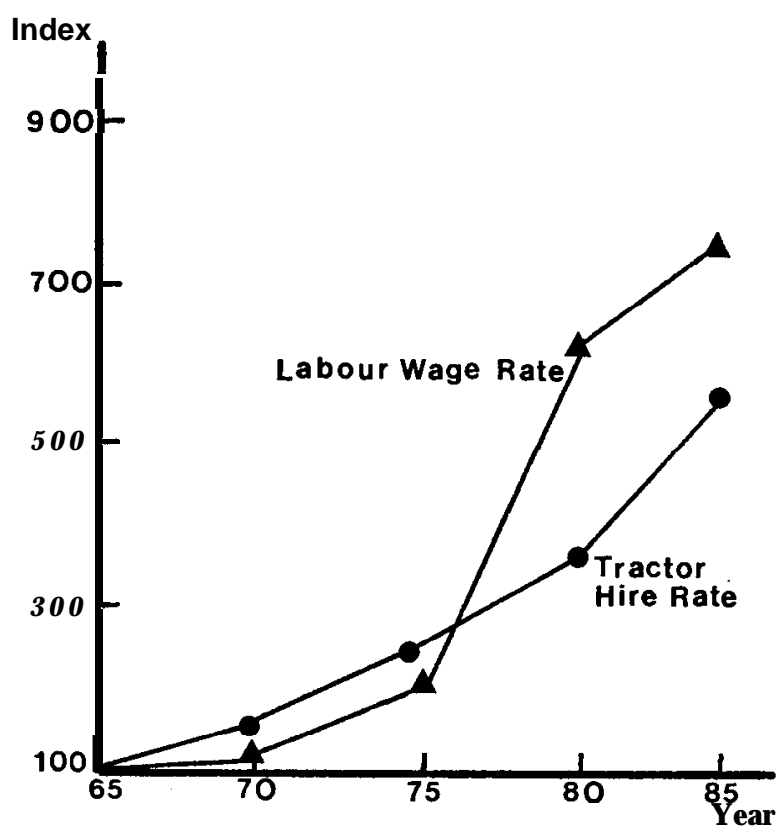

Fig. 6. Index of Tractor Hire Rates and Labour Wage Rates (Bulffao Operation) in Ambalantota Area (1965-84)

Note : $1965=100$

Source: Estimated on the basis of the data on tractor hire rates and labour wage rates which were collected from personal communication with a number of randomly selected farmers in Ambalantota area.

obviously will further reduce the competitive power held by the buffalo power based-labour intensive technology. In the future, tractor hire rates are unlikely to increase at the same rate as fuel prices, whereas in response to the ever-rising cost of living, labour wage rates will continue to rise. In consequence, while the animal draught power based-labour intensive technology would further lose its competitive power, its counterpart, mechanical power based-labour saving technology, would gain competitive power. Therefore mechanization would continue into the future.

\section{CONCLUSION}

On account of these evidences it can be concluded that the disintegration of the attama institution and the emergence of hired labour in it's place, paves the path for the mechanization of paddy land preparation in the peasant paddy farming sector. Once the way is opened, tractor hire rates and labour wage rates become crucial factors in determining farmers' decisions to mechanize the land preparation; and it appears that these both factors will accelerate mechanization. Since the socio-economic and cultural background 
which has cushioned the attama institution is subject to rapid change, the reciprocal exchange labour is highly unlikely to revive. Even in developing areas especially in new settlement schemes, there is no scope to emerge such an institution. Besides, the increasing emphasis on the time limitation on cultivation operations will further hamper the attama institution. Therefore the attama institution is likely to continue to disintegrate. Consequently, the animal draught power based labour intensive technology, having lost its strength to compete with its counterpart, is likely to decline in importance. However, in some areas where the proper operation of tractors and power tillers are less practical due to the reasons beyond the farmers' control, i. e. on boggy paddy fields in the wet zonal lower river valleys and on the paddy fields with small-sized liyaddas on rapid slopes in the hilly country, the draught animal power is likely to continue to hold its position.

\section{ACKNOWLEDGEMENTS}

The authors wish to thank Professor Jun Sakai, Department of Agricultural Engineering, Dr. Tsunemasa Kawaguchi and and Dr. Toshimi Umeki, Associate Professors and Dr. Satoshi Kai, Assistant Lecturer of the Department of Agricultural Economics, Kyushu University for their constructive comments on the first draft of this paper. The authors are extremely gratiture to $\mathrm{Mr}$. $\mathrm{N}$. L.A. Karunarathna, Assistant Lecturer, Department of Geography and Mr. S. K. Wimalaweera, Mr. P.V. Chandrasena, Mr. R.D.R. Dayananda, Mr. K.T.N. Rambanda and Mr. K.M.A. Prematilaka undergraduate students of the Sri Jayawardenapura University for their assistance with the field survey.

\section{REFERENCES}

Abeysinghe, Ariya 1980 Historical Evidence of Water Management in Ancient Sri Lanka. Economic Review, 6 (6 \& 7$): 6-7$

Das Gupta 1939 Economic Survey of Nine Villages of Galle District. Bulletin No. 11, Ministry of Labour, Industry and Commerce, Colombo

Goldsmith, E. 1983 Traditional Agriculture in Sri Lanka. The Ecologist, 12: 209-216

Gunasinghe, N. 1976 Social Change and the Disintegration of a Traditional System of Exchange Labour in Kandyan Sri Lanka. Economic Review, 2 (1): 5-8

Karunanayake, M. 1980 Traditional Exchange Labour in Hilly Country Sri Lanka. Sri Lanka Journal of Social Science, 2 (1) : 109-119

Tambaiah, S. J. 1963 Ceylon. In "The Role of Savings and Wealth in Southern Asia and West", Unesco

Ulluwishewa, R. and K. Tsuchiya 1984 A study of the Motivating Factors for Farm Mechanization in the Dry Zone of Sri Lanka. A Case Study: Unagaswewa Village. Bull. Inst. Trop. Agr. Kyushu Univ., 7: 91-117

University of Ceylon 1957 The Disintegration Village: A Socio-economic Survey. The Ceylon University Press, Peradeniya 